\title{
WASF2 wt Allele
}

National Cancer Institute

\section{Source}

National Cancer Institute. WASF2 wt Allele. NCI Thesaurus. Code C125110.

Human WASF2 wild-type allele is located in the vicinity of 1 p36.11 and is approximately 86 $\mathrm{kb}$ in length. This allele, which encodes Wiskott-Aldrich syndrome protein family member 2 protein, plays a role in signal transduction that regulates actin filament organization. 